\title{
Effect of co-administration of extracts of Vernonia amygdalina and Azadirachta indica on lipid profile and oxidative stress in hepatocytes of normal and diabetic rats.
}

\author{
P.E. Ebong ${ }^{1}$, I.J. Atangwho ${ }^{1 *}$, E.U. Eyong ${ }^{1}$, G.E. Egbung ${ }^{1}$ and E.V. Ikpeme ${ }^{2}$ \\ ${ }^{1}$ Department of Biochemistry, College of Medical Sciences, University of Calabar, P.M.B. \\ 1115, Calabar - Nigeria \\ ${ }^{2}$ Department of Genetics and Biotechnology, Faculty of Science, University of Calabar, \\ Calabar.
}

\begin{abstract}
Effect of combined administration of extracts of Vernonia amydalina (VA) and Azadirachta indica (Al) on oxidative stress indices and serum lipid profile of normal and diabetic rats was evaluated. Result indicated a significant decrease $(p<0.05)$ in catalase (CAT) activity, but non-significant decreases $(p>0.05)$ in superoxide dismutase (SOD) and glutathione peroxidase (GPx) activities, and in the extent of lipid peroxidation non-significant increase $(p>0.05)$ in malondialdehyde (MDA) concentration of untreated diabetic rats relative to the normal control. Treatment with combined extracts of VA and Al caused significant elevation in GPx, SOD and CAT activities, and reduction in MDA concentration in hepatocytes, hence antioxidant activity. This antioxidant potential was also demonstrated in normal rats which received the treatment. The combined extracts also caused mild increase and decrease in serum high density lipoprotein (HDL) cholesterol and triacylglycerol concentrations, but a respective significant $(p<0.05)$ decrease and increase in serum total cholesterol (TC) and anti-atherogenic index (HDL/TC) when compared to diabetic control. Co-administration of extracts of VA and Al may positively modulate the antioxidant defense system and prevent atherosclerosis in diabetes.
\end{abstract}

Keywords. Oxidative stress; lipid profile; diabetes; Vernonia amygdalina; Azadirachta indica

\section{INTRODUCTION}

Diabetes mellitus is a name given to a multiple of disorders with different etiologies, and characterised by derangements in carbohydrates, proteins and fats metabolism, caused by a complete or relative insufficiency in insulin secretion or action (Rodrigues et al., 1999). The multifaceted etiologies are in recent times thought to be the reason why a range of conventional and chemotherapeutic agents, though in use for over several decades have failed to completely address the problem (Tiwari and Rao, 2002). As single agents, they act only in part of the pathogenic process and to a partial extent only (Luna and Feinglos, 2001). For instance the sulfonylureas known to exert antidiabetic action by stimulating insulin release from pancreatic beta cells or by reducing hepatic clearance of the hormone (Luna and Feinglos, 2001) cannot be solely relied upon for treatment of type 2 diabetes mellitus (Zito et al., 2008), whose etiology is only distantly related to pancreatic $\beta$-cell function.
To circumvent this drawback of pharmacologic agents, traditional medicinal plants are heavily relied upon in the current search for appropriate agents in the management of diabetes. Leads provided by folk medicine (Rates, 2001) and the fact that plants are endowed with a variety of phytochemicals or bioactive compounds that are thought to act on a variety of targets by various modes and mechanisms (Tiwari and Rao, 2002; Zito et al, 2008) justify this claim. Besides, a combination of different types of agents from different plant sources - polyherbal formulation, can yet be used to enhance efficacy. For similar reasons, most conventional hypoglycemic agents with different intervention targets have been administered in combination with the aim of achieving better glycemic control (Luna and Feinglos, 2001). Although they are reported to be quite effective in reducing fasting plasma glucose, the approach has not been extensively studied (Ovalle and Bell, 1998) and the maximum agents so far combined as trail conventional therapy is three (3): Sulfonylurea, thiozolidinedioine and $\alpha$-glucosidase inhibitors (Luna and Feinglos, 2001). 
However, more than just three (3) agents can be present in medicinal plants and yet safer to the biological system, since always a compliment of phytochemicals exist especially when combined. Moreover, plant foods are thought to have acquired biological adaptations to the human system (Srinivasan, 2005). Polyherbal therapy according to Tiwari and Rao (2002) 'have the synergistic, potentiative, agonistic/antagonistic pharmacological agents within themselves (natural balance), and these work together in a dynamic way to produce maximum therapeutic efficacy with minimum side effects.

Vernonia amygdalina Del. (African bitter leaf) and Azadirachta indica A. Juss (neem) are two plants used traditionally in the management of diabetes in the African sub-Region and Asia respectively. Vernonia amygdalina Del. belongs to the Compositae family and grows extensively in a range of ecological zones in tropical Africa (Farombi, 2003). The antihyperglycemic action of the plant (NimeniboUadia, 2003; Akah et al., 2004) hypoglycermic effect (Gyang et al., 2004); hypolipidemic and antihyperlipidemic action of the aqueous leaf extract (Atangwho, et al., 2007a) and its protective effect on kidneys of diabetic rats (Atangwho, et al., 2007b) have been reported. On the other hand Azadirachta indica A. Juss belongs to the family Meliacae and the hypoglycemic action of its leaves, stem, and bark and seed oil have been articulated in a review by Biswas et al. (2002). Ebong, et al. (2006) has compared the ability of leaf - extracts from the two plants to regenerate beta - cells of pancreas of rats pretreated with alloxan, a beta-cell destructive agent. However, detailed scientific studies as per antidiabetic efficacies and modes (mechanisms) of the anti-diabetic action of these plants are not available. More so, no biochemical studies have been carried out with combined extracts from the two plants (polyherbal therapy) on the anti oxidative and hypolipidemic effects.

Oxidative stress and hence lipid peroxidation engendered by generation of free radicals (reactive oxygen species) and certain environmental factors including lifestyle is central in the onset of diabetes mellitus as well as the development of vascular and neurologic complications of the disease (Rosen et al., 2001). This phenomenon is independent of the type of diabetes and as such it remains controversial whether hyperglycemia is a cause or an effect of increased oxidative stress (Philips et al., 2004).
This study therefore assessed the efficacy of combined extracts of the two known antidiabetic plants - Vernonia amygdalina and Azadirachta indica in the control of lipid complications and oxidative stress usually associated with chronic diabetes. Alteration in biological processes by some minor food components and secondary plant metabolites is known to reduce the risk of chronic diseases in humans (Ugochukwu et al., 2003) such as diabetic mellitus. This may also be necessary in understanding the mode of action of such agents.

\section{MATERIALS AND METHODS}

Plant materials: Matured leaves of Vernonia amygdalina Del. and Azadirachta indica A. Juss were respectively collected from the Endocrine Research Farm, and the staff village, University of Calabar, after authentication. The leaves were rinsed severally with clean tap water to remove dust particles and debris and thereafter allowed to completely drain. The plant materials were separately cut and chopped with a knife after which one kilogram $(1 \mathrm{~kg})$ each of $A$. indica and $V$. amygdalina was homogenized in 1.95 and 2.25 liters of $80 \%(\mathrm{v} / \mathrm{v})$ ethanol respectively. The mixtures were allowed for $48 \mathrm{hrs}$ in the refrigerator at $4^{0} \mathrm{C}$ for thorough extraction of the plants' active components. These were firstly filtered with cheesecloth and later with Whatman No. 1 filter paper and the filtrates concentrated in vacuo at low temperature $\left(37-40^{\circ} \mathrm{C}\right)$ to about one tenth the original volume using a rotary evaporator. The concentrates were allowed open in a water bath $\left(40^{\circ} \mathrm{C}\right)$ for complete dryness yielding $40.54 \mathrm{~g}$ $(4.054 \%)$ and $34.71 \mathrm{~g}(3.471 \%)$ of greenish brown and brown oily substances for $V$. amygdalina and $A$. indica respectively. The extracts were then refrigerated at $2-8^{0} \mathrm{C}$ until use.

Animals: Sixty male albino rats of Wistar strain weighing about $140-180 \mathrm{~g}$ obtained from the animal house of the Department of Zoology and Environmental Biology, University of Calabar, Calabar, were allowed to acclimatize for three weeks in the animal house of the Department of Biochemistry. The animals were housed in well ventilated cages (wooden bottom and wire mesh top) and kept under controlled environmental conditions of temperature $\left(25 \pm 5^{\circ} \mathrm{C}\right)$, relative humidity $(50 \pm 5 \%)$ and 12 hour light / dark cycle. The animals were maintained on palletized Growers feed (Vital Feeds, Jos, Plateau State, Nigeria) and tap water ad libitum. 
Diabetes was induced by intraperitoneal injection of $65 \mathrm{mg} / \mathrm{kg}$ b.w. of streptozotocin (STZ) (Sigma St. Louis, MO, U.S.A) reconstituted in normal saline after a 12 hour fast. Control animals received saline only. Seven days after STZ treatment, diabetes was confirmed in STZ treated rats with a fasting blood glucose concentration $\geq 200 \mathrm{mg} / \mathrm{dl}$ using One Touch ${ }^{\circledR}$ Glucometer (Lifescan, Inc. 1995 Milpas, California, U.S.A) with blood obtained from the tail vein of the rats. The 60 rats were divided into 5 parallel groups consisting of a diabetic and non-diabetic pair of 6 animals each (table 1). The diabetic and nondiabetic animals were accordingly, treated with extracts and insulin as shown in table 1. The dosages of the plant extracts were as determined from preliminary work in our laboratory whereas insulin dose, NPH (5U/kg b.w. s.c.) was as previously used by Sonia and Srinivasan (1999). The plant extracts were administered via gastric intubation, twice per day (6.00am: $6.00 \mathrm{pm}$ ) and insulin once per day post prandial $(6.00 \mathrm{pm})$ for 28 days. At the end of the 28day treatment the rats were after 12 hour fast euthanized under chloroform vapor and sacrificed. Whole blood was collected via cardiac puncture, emptied into plain tubes and allowed to clot for about two hours. The clotted blood was thereafter centrifuged at $3,000 \mathrm{rpm}$ for 10 minutes and serum recovered from clotted cells and used for lipid profile analysis.

Table 1: Experimental design

\begin{tabular}{|c|c|c|c|c|c|}
\hline \multicolumn{3}{|c|}{ Diabetic rats } & \multicolumn{3}{|c|}{ Non-Diabetic rats } \\
\hline Group & $\begin{array}{l}\text { No. of } \\
\text { animals }\end{array}$ & Treatment & Group & $\begin{array}{l}\text { No. of } \\
\text { animals }\end{array}$ & Treatment \\
\hline $\mathrm{DC}$ & 6 & Placebo (Diabetic control) & $\mathrm{NC}$ & 6 & $\begin{array}{l}\text { Placebo (Non-Diabetic } \\
\text { control) }\end{array}$ \\
\hline $\mathrm{VA}_{\mathrm{ND}}$ & 6 & $\begin{array}{l}\text { V. amygdalina extract }(200 \mathrm{mg} / \mathrm{kg} \\
\text { b.w.) }\end{array}$ & $\mathrm{VA}_{\mathrm{D}}$ & 6 & $\begin{array}{l}\text { V. amygdalina extract } \\
(200 \mathrm{mg} / \mathrm{kg} \mathrm{b.w.)}\end{array}$ \\
\hline$A I_{N D}$ & 6 & A. indica extract (200mg/kg b.w.) & $A \mathrm{Al}_{\mathrm{D}}$ & 6 & $\begin{array}{l}\text { A. indica extract }(200 \mathrm{mg} / \mathrm{kg} \\
\text { b.w.) }\end{array}$ \\
\hline $\mathrm{VA} / \mathrm{Al} \mathrm{ND}_{\mathrm{ND}}$ & 6 & $\begin{array}{l}\text { V. amygdalina and } A \text {. indica } \\
\text { combined extracts }(100 \mathrm{mg} / \mathrm{kg} \mathrm{b.w.} \\
\text { each) }\end{array}$ & $\mathrm{VA} / \mathrm{Al}_{\mathrm{D}}$ & 6 & $\begin{array}{l}\text { V. amygdalina and } A \text {. } \\
\text { indica combined extracts } \\
(100 \mathrm{mg} / \mathrm{kg} \text { b.w. each) }\end{array}$ \\
\hline$H U_{N D}$ & 6 & Insulin (5 unit/kg b.w.) & $\mathrm{HU}_{\mathrm{D}}$ & 6 & Insulin (5 unit/kg b.w.) \\
\hline
\end{tabular}

Biochemical assays: The livers were also surgically removed and immediately perfused in heparinized saline $(0.9 \% \mathrm{NaCl})$ to remove blood cells and thereafter blotted with blotting paper then stored frozen. Exactly $1 \mathrm{~g}$ of the tissue was weighed and thoroughly homogenized in $10 \mathrm{ml}$ of freshly prepared phosphate buffer (20mM; pH 7.4). The homogenate was then centrifuged at $3,000 \mathrm{~g}$ for 10 minutes using table centrifuge (B. Bran Scientific and Instrument Company, England) and the supernatant decanted into clean tubes and used for MDA, SOD, GPx and CAT assays. The assay kits for determination of these oxidative stress indices were obtained from Oxis Research ${ }^{\text {TM }} 323$ Vintage Park Drive, Suite B Foster City, CA 94404-1136 U.S.A. The assay methods for SOD activity, total (free and proteinbound) (MDA) concentration, and CAT activity in the rat hepatocytes were based on the principles described by Nebot et al. (1983), Gernard-Monnier (1998) and Aebi (1984) respectively, whereas that for cellular GPx activity was Colorimetric based on Paglia and Valentine (1967). Assay kits obtained from Randox Laboratories Ltd., Admore Diamond Road, Crumlin, Co., Antrim, United Kingdom, Bt294QY were used to estimate serum lipids including total cholesterol, triacylglycerol and HDLcholesterol based on the method of Tiezt (1990).

Statistical analysis: The results were analysed for statistical significance by one way ANOVA using the SPSS statistical program and Post Hoc Test (LSD) between groups using MS excel program. All data were expressed as Mean \pm SEM. $P$ values $<0.05$ were considered significant.

\section{RESULTS}

Effect of extracts on serum lipid profile: Changes in serum lipids concentration following a 28-day treatment in this investigation is shown in tables 2 and 3. Serum HDL-cholesterol concentration in diabetic control rats which decreased significantly ( $p$ $<0.05)$ compared to non-diabetic control was increased in all diabetic treatment groups except the insulin treated group. These increases were however 
non significant $(p>0.05)$, except for the Al extract treated group in which significant HDL cholesterol increase was observed compared to diabetic control. The four treatments in normal rats also caused nonsignificant increases $(p>0.05)$ in HDL-cholesterol levels. Serum concentrations of total cholesterol (TC) and triacyglycerol (TG) were on the other hand significantly raised $(p<0.05)$ in diabetic control rats compared to non-diabetic control group. Treatments with extracts of $\mathrm{VA}, \mathrm{Al}$ only, and $\mathrm{VA}$ and $\mathrm{Al}$ combined, and insulin decreased these later indices. However the decreases were significant $(p<0.05)$ in total cholesterol levels only. The result of atherogenic index $(\mathrm{HDL} / \mathrm{TC})$ showed striking significant $(p<0.05)$ increase in all treatments (except insulin treated diabetic group) in diabetic rats relative to the diabetic control group. These increases compared well with the non diabetic control, hence these treatments can protect against atherosclerosis.

Table 2. Effect of treatments on serum lipid profile of non diabetic rats.

\begin{tabular}{|c|c|c|c|c|}
\hline Group / Treatment & HDL-Ch. (mg/dl) & T.Chol. (mg/dl) & $\mathrm{HDL} / \mathrm{TC}$ & $\mathrm{TG}(\mathrm{mg} / \mathrm{dl})$ \\
\hline $\mathrm{NC}$ & $41.06 \pm 4.74$ & $50.58 \pm 5.07$ & $1.08 \pm 0.19$ & $92.88 \pm 7.90$ \\
\hline $\mathrm{VA}_{\mathrm{ND}}$ & $50.68 \pm 8.80$ & $51.32 \pm 11.27$ & $0.99 \pm 0.18$ & $109.60 \pm 7.47$ \\
\hline $\mathrm{Al}_{\mathrm{ND}}$ & $50.14 \pm 2.94$ & $45.38 \pm 8.80$ & $1.17 \pm 0.34$ & $95.93 \pm 16.09$ \\
\hline $\mathrm{VA} / \mathrm{Al} \mathrm{I}_{\mathrm{ND}}$ & $50.08 \pm 3.00$ & $38.31 \pm 2.86$ & $1.30 \pm 0.28$ & $102.48 \pm 14.67$ \\
\hline $\mathrm{HU}_{\mathrm{ND}}$ & $53.48 \pm 3.70$ & $51.00 \pm 2.73$ & $1.05 \pm 0.06$ & $96.87 \pm 8.92$ \\
\hline
\end{tabular}

Mean $\pm \mathrm{SE}, \mathrm{n}=6, \mathrm{ND}=$ non diabetic, $\mathrm{HU}=$ insulin, $\mathrm{a}=\mathrm{p}<0.05$ vs $\mathrm{DC}, \mathrm{d}=\mathrm{p}<0.05$ vs HU.

Table 3. Effect of treatments on serum lipid profile of diabetic rats.

\begin{tabular}{|c|c|c|c|c|}
\hline Group / Treatment & HDL-Ch. (mg/dl) & T.Chol. (mg/dl) & HDL/TC & $\mathrm{TG}(\mathrm{mg} / \mathrm{dl})$ \\
\hline $\mathrm{DC}$ & $23.45 \pm 7.94$ & $153.07 \pm 3.72$ & $0.44 \pm 0.17$ & $149.38 \pm 24.89$ \\
\hline NC & $41.06 \pm 4.74^{\mathrm{a}}$ & $50.58 \pm 5.07^{a}$ & $1.08 \pm 0.19^{a}$ & $92.88 \pm 7.90^{\mathrm{a}}$ \\
\hline$V A_{D}$ & $30.85 \pm 3.58$ & $72.70 \pm 29.09^{a}$ & $0.85 \pm 0.37^{a}$ & $74.97 \pm 3.94^{\mathrm{a}}$ \\
\hline$A I_{D}$ & $44.63 \pm 5.16^{\mathrm{a}, \mathrm{d}}$ & $47.23 \pm 9.97^{a}$ & $1.02 \pm 0.20^{\mathrm{a}}$ & $105.87 \pm 36.28$ \\
\hline $\mathrm{VA} / \mathrm{AI} \mathrm{I}_{\mathrm{D}}$ & $34.28 \pm 4.00$ & $46.35 \pm 10.67^{a}$ & $0.90 \pm 0.25^{a}$ & $104.85 \pm 16.50$ \\
\hline $\mathrm{HU}_{\mathrm{D}}$ & $22.07 \pm 7.00$ & $58.35 \pm 6.73^{a}$ & $0.37 \pm 0.08$ & $99.15 \pm 10.79$ \\
\hline
\end{tabular}

Mean $\pm \mathrm{SE}, \mathrm{n}=6, \mathrm{ND}=$ non diabetic, $\mathrm{DC}=$ diabetic control, $\mathrm{HU}=$ insulin, $a=p<0.05$ vs $\mathrm{DC}, \mathrm{d}=\mathrm{p}<0.05$ vs HU.

Effect of extracts on oxidative stress markers: Effect of treatment with extracts of VA and Al only, $\mathrm{VA}$ and $\mathrm{Al}$ combined and insulin for 28days on hepatocyte indices of oxidative stress including GPx, SOD and CAT activities and MDA concentration is shown on Fig. 1. Treatment with STZ produced a non significant $(p>0.05)$ decrease in GPx activity in diabetic control rats compared to non diabetic control.
Administration of extracts of VA and Al singly caused non significant change $(p<0.05)$ in GPx activity compared to diabetic control, but treatment with combined extracts of VA and Al, significantly increased $(p<0.05)$ GPx activity relative to both diabetic and non-diabetic controls. Effect of insulin treatment was not significantly different $(p>0.05)$ from that of combined extract treatment. Increase in 
GPx activity was also observed in non-diabetic treated groups, but this was significant $(p<0.05)$ only in groups treated with $\mathrm{Al}$ extracts alone compared to non-diabetic control.
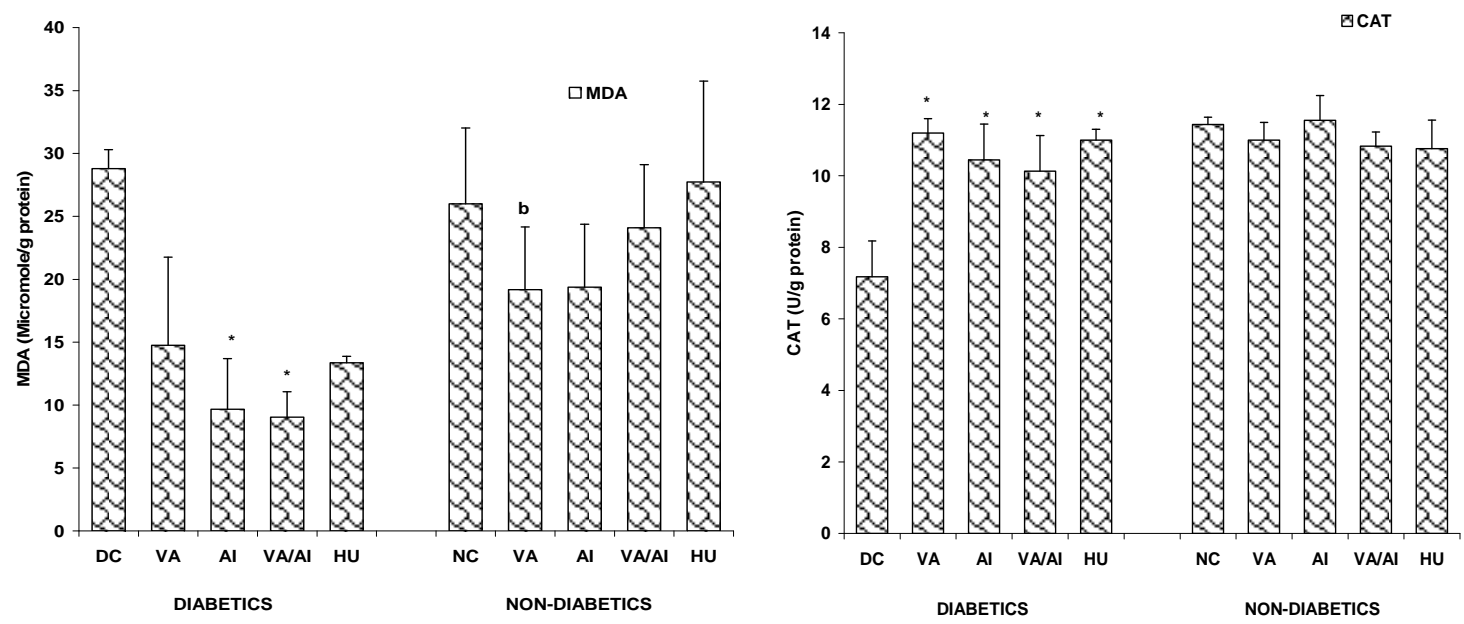

(a)

(b)

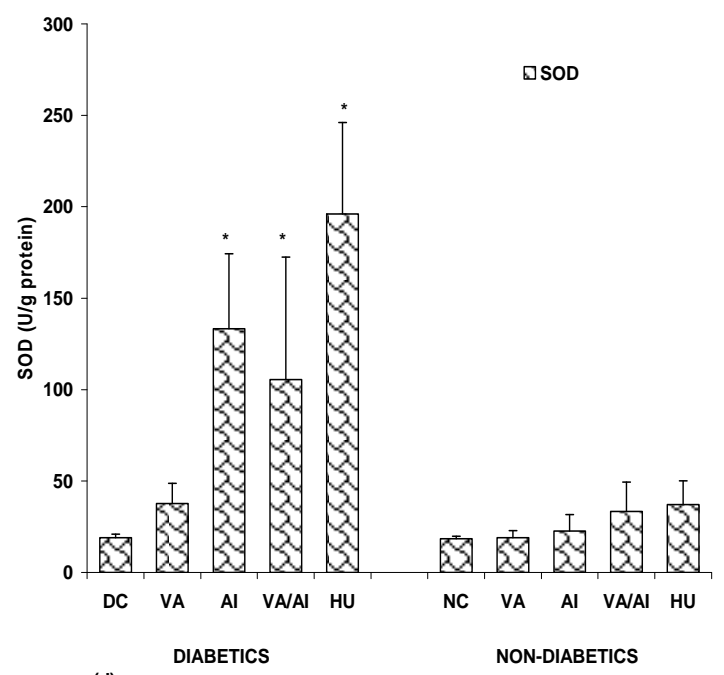

Fig.1. (a) Malondialdehyde concentration, (b) catalase activity, (c) glutathione peroxidase activity and (d) superoxide dismutase activity in hepatocytes of diabetic and non-diabetic rats.

Values are mean \pm SEM, $n=6 .{ }^{*}=p<0.05$ vs DC; $a=p<0.05$ vs NC, $b=p<0.05$ vs HU.

There was no significant difference $(p>0.05)$ between SOD activity of diabetic and non-diabetic controls. However, treatments with Al extracts only, $\mathrm{VA}$ and $\mathrm{Al}$ combined and insulin caused significant increase $(p<0.05)$ in SOD activity while the increase with VA extract was non significant $(p>0.05)$, all compared to diabetic control. There was no significant difference in SOD activities among the non-diabetic test rats which received the extract treatment. Catalase activity which was significantly decreased in diabetic control rats compared to nondiabetic control, became significantly increased after 28 days treatment with extracts of $\mathrm{VA}$ and $\mathrm{Al}$ singly, $\mathrm{VA}$ and $\mathrm{Al}$ combined and insulin, and also compared well with normal control. No significant changes were observed among the non-diabetic test rats which received the extract treatment. MDA concentration was non significantly raised $(p>0.05)$ in diabetic control rats compared to non diabetic control. There was non significant decrease $(p>0.05)$ in MDA of 
diabetic rats treated with VA extracts and insulin, but significant decreases $(p<0.05)$ in groups treated with extracts of $\mathrm{Al}$ alone and combined extracts of VA and Al. Treatments with extracts singly and in combination in normal rats caused non-significant decreases in MDA concentration compared to normal control.

\section{DISCUSSION}

Altered lipid metabolism - hypertriacylglycerolemia and hypercholesterolemia, are common occurences of chronic uncontrolled diabetes and usually contribute to the pathogenesis of vascular complications in diabetes (Meyes, 2003; Scoppola et al., 2001). These accumulation in blood of cholesterol and triacylglycerol of diabetes was also confirmed in this study.

Following a 28-day administration of our extracts singly and in combination, significant decreases were seen and improvement even in the atherogenic index of treated groups. This report for VA extracts is consistent with our earlier reports (Atangwho et al., 2007a; Eteng et al., 2008) and the observed antihyperlipidemic effect of $\mathrm{Al}$ extracts had also earlier been reported in STZ treated rats (Chattopadhyay and Bandopadhyay, 2005) and malaria treated human patients (Njoku et al., 2001). However, for the first time combined extracts from these two plants have also shown antihypercholesterolemia and improved atherogenic index in diabetic rats.

Chronic hyperglycemia is known to precipitate complications in diabetes via formation of advanced glycosylation end products and this eventually tend to lower HDL- cholesterol levels, the protective molecule against artherosclerosis (Robinson and Johnson, 1997) probably due to glycation of the protein portion of the molecule. This was observed in this study and administration of extracts caused HDL cholesterol increases although the increase was significant only with Al extract. Although Chattopadhyay and Bandopadhyay (2005) had reported a non significant increase with Al treatment, the difference in extent of increase may arise from the duration of administration. Whereas Chattopadhyay and Bandopadhyay treated for 7 days only, in the present study, treatment lasted for 28days. Another support for our result is the fact that Njoku and co-workers (2001) also reported significant increase in HDL- cholesterol levels of malaria patients treated with crude neem extracts relative to both malaria controls and chloroquine treated patients. Although the increases with VA alone, and VA plus Al treatments were non significant, they were both comparable with non-diabetic control and also several folds higher than insulin treated group, which rather tended towards a decrease. Moreso, their respective indices of artherogenic risk showed a protection against atherogenesis. Perhaps a longer duration was needed to evoke significant changes of HDL- cholesterol levels in those treatment groups. The extracts used in this study, both singly and as combined treatments have the potentials to protect against artherosclerosis and its associated or incidental cardiovascular complications usually induced by chronic hyperglycemia of diabetes.

The antioxidant enzymes (GPx, SOD and CAT) and the actual reactive substances produced from peroxidation reactions such as malondialdehyde (MDA) and thiobarbituric acid (TBA) have been used to study peroxidation and oxidation generally in biological systems. In this study GPx and CAT activities were decreased in hepatocytes of STZ diabetic rats compared to non-diabetic rats. Decreases in GPx activities in liver tissues of STZ rats (Ugochukwu et al., 2003, Nwanjo, 2007) and of diabetic patients (Ozmen et al., 2000); and CAT activities in hepatocytes of STZ diabetic rats (Nwanjo, 2007, Kasavulu et al., 2000); liver, heart and kidneys of human patients (Asamaya et al.,1989) have similarly been reported. Streptozotocin used in induction of diabetes and the sustained hyperglycemia are known pathogenic factors of free radical generation or increased lipid peroxidation (Tatsuki et al., 1997; Szkudelski, 2001; Goycheva et al., 2006) and the resulting radicals do induce the antioxidant defense enzymes particularly in the liver, the tissue with the most abundant antioxidant defense enzymes (Tatsuki et al., 1997), to cause an initial increase. But if this process continues and becomes chronic, the enzymes systems may become overwhelmed and the induction system also exhausted or worn out, hence the observed decrease in antioxidant enzymes.

Ugochukwu and co-workers (2003) have attributed the decrease to inactivation of the enzymes by the radicals or glycation of the enzyme protein themselves. Ozmen et al. (2000) have also indicated in their report, an inverse relationship between SOD, CAT and GPx activities in liver, heart and kidneys, and ROS concentration. This is so because even other chronic pathologic and physiologic changes, 
where lipid peroxidation progressively increases and then climaxed, including aging, cancer, cardiovascular diseases, obesity, etc. decreased antioxidant enzyme defense system has also been reported (Tiwari and Rao, 2002, Amirkhizi et al., 2007). The selective decrease in GPx and CAT activities as seen in this study may imply also a selective increase in the type of radical produced $\left(\mathrm{H}_{2} \mathrm{O}_{2}\right.$ concentration) since this is a common substrate to both GPx and CAT. Superoxide dimutase activity in diabetic control rats was not altered significantly due probably to the efficient system of the enzyme or decreased production of superoxide radicals within the study period. Non significant change of SOD activities in diabetic vasculature (Pieper et al., 1995) and significant increase in activities in diet induced obesed rat models (Dobrian et al., 2000; Vincent et al., 1999) have both been reported. The observed non significant increase in MDA concentration though, contrasting with the prevalent view, is consistent with report of other researchers. Tatsuki et al. (1997) in comparing lipid peroxidation in pancreas and other organs in STZ diabetic rats observed also a non significant change in MDA levels in hepatocytes two weeks after STZ treatment and even at the end of their experiment, 7 weeks after. MDA concentration in diabetic condition is therefore both tissue (organ) and time dependent.

Administration of combined extracts of $\mathrm{VA}$ and $\mathrm{Al}$ was able to cause a significant response - increase in GPx activities even far and above treatments with single extracts of VA and $\mathrm{Al}$ which did not significantly change as per GPx. Given that the initial increase in activities of the enzyme was accasioned by production of radicals (their substrates), the extracts must have scavanged/ mopped up or 'quenched' these produced radicals or even reversed the pathogenic factor (hyperglycemia) which induces lipid peroxidation, thereby decreasing the utilization and inactivation of the antioxidant enzymes to cause their eventual increase in activities particularly in the tissue. The argument also holds true for observed increase in SOD activity and decrease in MDA concentration in the hepatocytes. Although, monotherapy with VA extracts did not cause significant changes in GPx and SOD activities and MDA concentration, this was positively modulated by Al extracts when combined - potential positive synergy. This action by the extracts obviously implies that the extracts must be endowed with numerus phytochemical antioxidants, since the process by which diabetes was induced - STZ, was via oxidants generation (Szkudelski, 2001). Baynes and Thorpes (1999) believed that this is like pouring water (antioxidants) to a burning house (diabetes). The antioxidant properties of $\mathrm{Al}$ in STZ diabetic rat models (Madhi et al., 2003), its phytochemical antioxidants (Biswas et al., 2002) and its ability to protect the hepatocytes against isoniazid, rifampian, pyrazinamide (all antitubercular drugs) (Kale et al., 2003) and paracetamol (Chattopadhyay and Bandyopadhyay, 2005) induced toxicities, classical cases of oxidative stress process have been reported. Three flavones with antioxidant activities more potent than the classical antioxidant, butylated hydroxy-toluene at equal concentrations have also been isolated from VA (Igile et al., 1994) and the antioxidant property of VA (significant reduction of MDA in STZ diabetic rats) also reported (Nwanjo, 2005). Besides, flavonoids, polyphenols, vitamins $A$, $\mathrm{E}$ and $\mathrm{C}$, and mineral elements including $\mathrm{Se}, \mathrm{Cu}, \mathrm{Zn}$ and $\mathrm{Cr}$ have been demonstrated in the leaves of VA and Al (Atangwho, 2009). These phytochemical antioxidants may have scavenged the radicals, hence caused an increase in the enzyme activities. Moreso, the enzymes are metalloenzymes, the presence of these micronutrients in the extracts may also have boosted their production and hence their increased activities. For instance, the activity of GPx, a selenium requiring enzyme, was seen to be higher significantly in Al treated compared to VA; and determined selenium concentration in leaves of $\mathrm{Al}$ were significantly higher in $\mathrm{Al}$ compared to VA (Atangwho, 2009). It is plausible that when the extracts were combined, selenium levels were boosted over single extracts, hence the observed relatively higher increase in GPx activity of the combined extracts treated group. There is also a possibility of potentiating the insulin-like phytochemicals in these two extracts by combination since the effect parallels that of insulin as per GPx and CAT activities. Some phytochemicals in antidiabetic plants are known to possess some insulin-like action and insulin-memetic properties (Yeh et al., 2003). According to these authors, the substances whose chemistry is yet uncertain, upregulate insulin receptors, facilitate glucose uptake and metabolism, and enhance insulin sensitivity. A combination of extracts of VA and Al may therefore be more beneficial and useful relative to individual extracts in diabetes management as antioxidant defense system, hence a rich raportoire of free radical quenching components and for prevention of atherosclerosis of diabetes mellitus. 


\section{REFERENCES}

Aebi H 1984 Catalase in vitro. Methods Enzymol. 105121 $-126$

Akah P, Njoku O, Nwanguma A and Akunyili D (2004) Effects of aqueous leaf extracts of Vernonia amygdalina on blood glucose and triglyceride level of alloxan-induced diabetic rats (Rattus rattus). Ani. Res. Int'l. 1 90-94

Amirkhizi $F$, Siassi $F$, Minaie S, Djalali M, Rahimi A and Chamari M (2007) Is obesity associated with increased plasma lipid peroxidation and oxidative stress in women. ARYA Atheroscler. J. 2189 - 192

Asayama K, Hayashibe H, Dobashi K, Niitsu T, Miyao A and Kato K (1989) Antioxidant enzyme status and lipid peroxidation in various tissues of diabetic and starved rats. Diab. Res. $1285-91$

Atangwho, I. J. (2009) Biochemical impact of combined administration of extracts of Vernonia amygdalina and Azadirachta indica on stz diabetic rat models, Ph.D. thesis, University of calabar, Calabar

Atangwho I J, Ebong P E, Eteng $\mathrm{M} U$, Eyong $\mathrm{E} U$ and Obi A U (2007b) Effects of Vernonia amygdalina Del. leaf on kidney function of diabetic rats. Int'I J Pharm. 3 143-148

Atangwho I J, Ebong $\mathrm{P} \mathrm{O}$, Eyong $\mathrm{M} \mathrm{U}$, Eteng $\mathrm{M} \mathrm{U}$ and Uboh F E (2007a) Vernonia amygdalina Del.: A potential prophylactic antidiabetic agent in lipids complication. Glob. J. Pure Appl. Sci. 13 103-106

Baynes, J. W. \& Thorpe, S. R. (1999). Role of oxidative stress diabetic complications: a new perspective on an old paradigm. Diabet. 48(1): 1 - 9

Biswas K, Chattepadhya I, Banergee R $\mathrm{K}$ and Bandyopadhyayi U (2002) Biological activities and medicinal properties of neem (Azadirachta indica). Curr. Sci. 82 1336-1346

Chattopadhay R R and Bandyopadhyoy M (2005) Possible mechanism of hepatoprotective activity of Azadirachta indica leaf extract against paracetamol-induced hepatic damage in rats: part III. Indian J. Pharm. 37 $184-185$

Dobrian A D, Davies M J, Prewitt R I and Lauterio T J (2000). Development of hypertension in a rat model of diet-induced obesity. Hyperten. 351009 - 1015

Ebong P E, Atangwho I J, Eyong E U, Ukwe C and Obi A U (2006) Pancreatic beta cell regeneration: A prabable parallel mechanism of hypoglycemic action of
Vernonia amygdalina Del. and Azadirachta indica. Proc. Int'I Neem Conf. Kunming, China pp 83-89

Eteng M U, Bassey B J, Atangwho I J, Egbung G E, Eyong E U, Ebong P E, and Abolaji A O (2008) Biochemical indices of macrovascular complications in diabetic rat model: Compared effects of Vernonia amygdalina, Catharantus roseus and chloropamide. Asian J. Biochem. 3 228-234

Farombi E O (2003) African indigenous plants with chemotherapeutic potentials and biotechnological plants with prodution of bioactive prophylactic agents. Afri. J. Biotech. 2 662-671

Gerard-Monnier (1998) Method of Colorimetric Analysis of Malonic Dialdehyde and 4-Hydroxy-2-enaldehydes as Indexes of Lipids Peroxidation, Kits for carrying out Said Method, Substituted Indoles for Use in Said Method and their Preparation; US Patent No. US5726063.

Goycheva P, Gadjeva V and Popov B (2006) Oxidative stress and its complications in diabetes mellitus. Trakia J. Sci. $41-8$

Gyang S S, Nyam D D and Sokomba E N (2004) Hypoglycemic activity of Vernonia amygdalina (Chloroform extract) in normglycamic and alloxaninduced hyperglucemic rats. J. Pharm. Biores. 1: 1015.

Igile G O, Oleszek W, Jurzysta M, Burda S, Fafunso M and Fasanmade A A (1994). Flavonoids from Vernonia amygdalina and their antioxidant activities. J. Agric. Food Chem. 422445 - 2448

Kale B P, Kothekar MA, Tayade H P and Jaju J B (2003) Effects of aqueous extracts of Azadirachta indica leaves on hepatotoxicity induced by antitubercular drugs in rats. Indian J. Pharm. $35177-180$

Kesavulu M M, Giri R, Kameswaraa R B and Apparao C (2000) Lipid peroxidation and antioxidant enzyme levels in type 2 diabetics with microvascular complications. Diabet. Metab. $26387-92$

Luna B and Fienglos M N (2001) Oral agents in the management of type 2 diabetes mellitus. Am. Fam. Phys. $631747-1756$

Madhi A A, Chandra A, Singh R K, Shukia S, Mishra L C and Ahmad S (2003) Effect of herbal hypoglycemic agents on oxidative stress and antioxidant status in diabetic rats. Indian J. Clin. Biochem. 18 8-15

Meyes P A 2003 Lipid transport and storage; in Harper's Biochemistry (25th ed) (New York: McGraw-Hill) pp 268-284 
Nebot C, Moutet $M$, Hulet $P, X u J ~ Z$, Yadan $J$ and Chaudiere $J$ (1993) Spectrophotometric Assay of Superoxide Dimutase Activity Based on the Activated Autoxidation of a Tetracyclic Catechol. Analyt. Biochem. $214442-451$

Nimenibo-Uadia R (2003) Effect of Vernonia amygdalina in alloxan-induced diabetic albino rats. J. Med. Lab. Sci. 12 25-31

Njoku O U, Alumanah E O and Meremikwe C U (2001) Effect of Azadirachta indica extracts on plasma lipid levels in human malaria. Boll. Chem. Formac. - Anno. $140365-370$

Nwanjo H U (2005) Efficacy of aqueous leaf extract of Vernonia amygdalina on plasma lipoprotein and oxidative status in diabetic rat models. Nigerian $\mathrm{J}$. Physiol. Sci. $2039-42$

Ovalle F and Bell D S H (1998) Triple oral antidiabetic therapy in type 2 diabetes mellitus. Endocrinol. Pract. $4146-7$

Ozmen D, Ozmen B, Esin E, Guner I, Sara H and Bayindir O (2000) Lens peroxide dismutase and catalase activities in diabetic cataract. Turkish J. Endocrinol. Metab. $11-4$

Paglia D E and Valentine W N (1967) Colorimetric assay for cellular glutathione peroxidase. J. Lab. Clin. Med. $70158-169$

Philips M, Cataneo R N, Cheema T and Greenberg J (2004). Increased breath biomerkers of oxidattive stress in diabetes mellitus. Clinica Chimina Acta 344 $189-194$

Pieper G M, Jordan M, Dondlinger L A, Adams M B and Roza A M (1995) Peroxidation stress in diabetic blood vessels. Reversal by pancreatic transplantation. Diabet. $44884-889$

Rates S M 2001 Plants as source of drugs. Toxicon. 39 $603-613$

Robinson G and Johnston D E (1997) Metabolic disorder: Diabetes; in Mechanisms of disease. An introduction to clinical science (1st ed) (eds) G Robinson and D E Johnston (Combridge: Combridge University Press)

Rodrigues B, Poucheret $P$, Betell $M$ L and McNeill J N (1999) Streptozotocin - Induced Diabetes: Induction, Mechanism(s), and Dose Dependency; in Experimental Models of Diabetes (ed) $\mathrm{J} \mathrm{H}$ McNeill (USA: CRC Press LLC) pp 3-17
Rosen P, Nawroth P P, King G, Moller W, Tritschler H J and Packer $L$ (2001) The role of oxidative stress in the onset and progression of diabetes and its complications: a summary of a Congress Series sponsored by UNESCO - MCBN, the American Diabetes Association and German Diabetes Society. Diabetes Metab. Res. Rev. 17189 - 212

Scoppola A, Montechi F R, Mezinger G and Lala A (2001) Urinary mevalonate excretion of rats in type 2 diabetes: role of metabolic control. Atherosclorosis 156 $357-361$

Sonia B and Scrinivasan B P (1999) Investigations into the anti-diabetic activity of Azadirachta indica. Indian $\mathrm{J}$. Pharm. $31138-141$

Srinivasan K (2005) Plant foods in the management of diabetes mellitus: spices as beneficial antidiabetic food adjuncts. Int`I J. Food Sci. Nutri. 56 399-414

Szkudelski T (2001) The mechanism of alloxan and streptozotocin action in B cells of the rat pancreas. Physiol. Res. $50536-546$

Taksuki R, Satoh K, Yamamoto A, Hoshi K and Ichihara K (1997). Lipids Peroxidation in the Pancreas and Other Organs in Streptozotocin Diabetic Rats. Japan J. Pharm. 75 267-273

Tietzt N W (1990) Clinical Guide to Laboratory Tests; 2nd ed (Philadelphia: W B Saunders Company) pp 554556

Tiwari A K and Rao J M (2002) Diabetic mellitus and multiple therapeutic approaches of phytochemicals: Present status and future prospects. Curr. Sci. 83 3037

Ugochukwu N H, Babady N E, Cobourne M and Gasset S $R$ (2003) The effect of gongronema latifolium extracts on serum lipid profile and oxidative strss iindices in hepatocytes of diabetic rats. J. Biosci. $281-5$

Vincent H K, Powers S K, Stewart D J, Shanely R A, Demirel $H$ and Naito $H$ (1999) Obesity is associated with increased myocardial oxidative stress. Int'I J. Obesity Rel. Metab. Disord. $2367-74$

Yeh G Y, Eisenberg D M, Kaptcuk T J and Philips R S (2003) System review of herbs and dietary supplements for glycemic control in diabetes. Diabet. Care $261277-1294$

Zito S W, Shinde J, Chen I-C S, Taldone T and Barletta M (2008) Oral hyperglycemics: a review of chemicals used to treat type 2 diabetes. Curr. Bioactive Compds. $468-85$. 